\title{
Tolerance to Cucumber Mosaic Virus in Pepper: Development of Advanced Breeding Lines and Evaluation of Virus Level
}

\author{
Moshe Lapidot, Department of Virology, Ilan Paran, Department of Plant Genetics, and Rachel Ben-Joseph, De- \\ partment of Virology, Agricultural Research Organization, The Volcani Center, Bet Dagan 50250, Israel; Serge \\ Ben-Harush, Hazera Seed Company Kiryat Gat, Israel; and Meir Pilowsky, Department of Plant Genetics, Shlomo \\ Cohen, Department of Virology, and Chen Shifriss, Department of Plant Genetics, Agricultural Research Organi- \\ zation, The Volcani Center
}

\begin{abstract}
Lapidot, M., Paran, I., Ben-Joseph, R., Ben-Harush, S., Pilowsky, M., Cohen, S., and Shifriss, C. 1997. Tolerance to cucumber mosaic virus in pepper: Development of advanced breeding lines and evaluation of virus level. Plant Dis. 81:185-188.

Tolerance to cucumber mosaic virus (CMV) was introduced from an Indian small-fruited hot pepper accession, Perennial, into several bell-type sweet pepper lines by means of pedigree and backcrossing breeding procedures. Tolerance was determined to be incompletely dominant and quantitatively inherited. Breeding lines with variable degrees of tolerance were developed based on inspection of visual symptoms after mechanical inoculation. The breeding lines were subsequently tested for their agronomic performance in the field after mechanical inoculation. Their levels of tolerance in the field closely resembled their previous performances in the greenhouse. There was no association between virus accumulation levels in the upper leaves, as determined by enzyme-linked immunosorbent assay (ELISA), and the degree of tolerance to the virus, as determined by either visual symptoms or field performance. We concluded that the basis for developing tolerant breeding lines from Perennial is primarily their ability to recover from high virus titer and not their restriction of virus multiplication.
\end{abstract}

Cucumber mosaic virus (CMV), the type member of the cucumoviruses, is one of the most devastating viruses in pepper all over the world $(4,10)$. In a recent survey of pepper viruses (15), the most frequently mentioned was tobacco mosaic virus followed by CMV. CMV is transmitted mainly by the green peach aphid, Myzus persicae, and by Aphis gossypii, but it can be transmitted by other species of aphids (10).

For many years, pepper breeders have sought sources for resistance to CMV, but factors such as plant age, environmental conditions, and inoculation techniques complicated the evaluation of promising genetic material. Pochard and coworkers (7-9,11-13) screened a large amount of diverse genetic material and identified the accession Perennial as tolerant to CMV. Perennial is an Indian hot pepper accession (Plant Introduction Station, New Delhi) of a small-fruited type $(0.8 \times 3.0 \mathrm{~cm}, 0.8 \mathrm{~g})$.

The inheritance of tolerance to CMV from Perennial was examined in several

Corresponding author: Moshe Lapidot

E-mail: vpmoshe@volcani.agri.gov.il

Contribution from the Agricultural Research Organization, The Volcani Center, Bet Dagan, Israel. No. 1753-E, 1995 series.

Accepted for publication 8 November 1996.

Publication no. D-1996-1217-05R

(C) 1997 The American Phytopathological Society studies; however, inconsistent results were obtained, which may be attributed to a differential response of Perennial to different CMV isolates (5). In India, the CMV resistance of Perennial and of three similarly resistant accessions was considered to be monogenic recessive (14). Segregation studies were carried out following two inoculations, and the symptomless plants remained virus free until the end of the season (14). Bansal et al. (1) demonstrated that Perennial and three other varieties are practically immune to CMV in Punjab, India. Rusco and Csillery (13), using Fulton's strain of CMV (3), compared Perennial with other accessions. Perennial and Yolo-Y, for example, showed 0.031 and 31 local lesions per leaf, respectively, and therefore Rusco and Csillery (13) used Perennial as the resistant donor and Fulton's CMV strain for selection and breeding. From different $F_{2}$ populations, they suggested two modes of inheritance: monogenic recessive and partially dominant (13). In France $(7,12)$, Perennial was determined to be tolerant to CMV, since slight mosaic symptoms appeared after inoculation at several different stages of plant development. Perennial, however, had the ability to recover from CMV mosaic symptoms. The tolerance was determined to be recessive and polygenic (12).

In this manuscript, we describe inheritance studies of the CMV tolerance derived from Perennial and the transfer of the tolerance to the background of sweet, bell- type peppers. The evaluation of these lines was based on symptom development in the greenhouse, field performance after inoculation, and virus accumulation as determined by enzyme-linked immunosorbent assay (ELISA).

\section{MATERIALS AND METHODS}

Virus. A field isolate of CMV was originally collected from peppers in the coastal region of Israel and maintained in an insect-proof greenhouse. The culture was propagated in cucumber plants and renewed every 2 to 3 weeks by mechanical inoculation. Based on serology (Sanofi Diagnostics, Pasteur, France), our isolate was found to belong to subgroup I.

Inoculation. CMV source plant (cucumber) leaves were triturated, and extracts were diluted in inoculation buffer (20 mM potassium phosphate, $\mathrm{pH}$ 7.0, 1 mM EDTA) and applied to Carborundumdusted leaves of target plants. Plants were kept at 25 to $27^{\circ} \mathrm{C}$ in a temperature-controlled greenhouse and were mechanically inoculated twice: at the first true-leaf stage and again 2 to 3 days later. Plants were scored, based on symptom appearance, 2 to 4 weeks after inoculation.

Inheritance studies. Perennial, the donor of tolerance to CMV, was obtained from G. Marchoux (INRA, Montfavet, France) and crossed with bell-type varieties Maor, Meiri, and 1190 (Hazera Seed Company, Israel). From each cross, several $\mathrm{F}_{1}$ plants were grown and crossed to produce $\mathrm{F}_{2}$ and $\mathrm{BC}_{1}$ populations. The tolerant $\mathrm{F}_{2}$ plants were saved for selfing and for backcrossing to the above bell-type parents. From the $\mathrm{F}_{3}$ to $\mathrm{F}_{6}$ generations of $\mathrm{BC}_{5}$ progenies, selection and selfing of CMVtolerant individuals were carried out in order to obtain several homozygous lines with variable degrees of tolerance to the virus.

Field performance. Based on greenhouse evaluation of advanced breeding lines $\left(\mathrm{BC}_{5} \mathrm{~F}_{3}-\mathrm{F}_{6}\right)$, a field study was conducted to evaluate the yielding potential of six selected lines. The tested seedlings were inoculated mechanically prior to transplanting in the field. Each line was planted in paired inoculated and noninoculated (control) rows on 1-m-wide beds, with 15 plants per row. The withinand between-rows spacing were 0.4 and 
$0.6 \mathrm{~m}$, respectively. Each pair of rows represented a replication of the experiment, and in total seven randomly distributed replicates were planted in the field. There was no virus spread between the inoculated and the noninoculated plants in the field; i.e., no symptoms were observed on the control noninoculated plants. When the first two or three fruits per plant had turned red, a single harvest of all the marketablesized mature fruits was performed. The data (number of fruits, average fruit weight, and fruit quality) were taken individually from each of 10 plants per row and were averaged for all rows.

Virus detection. Viral antigen was detected by using direct double-antibody sandwich ELISA, essentially according to Clark and Adams (2). Microtiter plates were coated with anti-CMV antibodies (Agrilab Biotechnology Ltd., Israel) diluted 1:1,000 in coating buffer and incubated for 12 to $16 \mathrm{~h}$ at $4^{\circ} \mathrm{C}$. Samples $(0.1$ g) were taken from greenhouse-grown plants from the uppermost leaf (first leaf from the top to attain a length of $3 \mathrm{~cm}$ ) and homogenized in $1 \mathrm{ml}$ of phosphate-buffered saline containing $0.05 \%$ Tween 20 and $2 \%$ polyvinylpyrrolidone (sample buffer). The homogenized tissue was collected and centrifuged, and $200 \mu \mathrm{l}$ of the supernatant was added to the coated microplate and incubated for 12 to $16 \mathrm{~h}$ at $4^{\circ} \mathrm{C}$. Alkaline phosphatase-conjugated anti-CMV antibodies (Agrilab) were added, and the combination was incubated for $3 \mathrm{~h}$ at $37^{\circ} \mathrm{C}$, followed by a color reaction using the substrate $p$-nitrophenyl phosphate. Color was allowed to develop for 1 to $2 \mathrm{~h}$ at room temperature, and absorbance values $(410 \mathrm{~nm})$ were determined with a colorimeter.

\section{RESULTS}

Inheritance studies. We screened various pepper accessions that were documented as resistant or tolerant to CMV (Table 1) and found that only Perennial and Pochard's androgenic dihaploids (ADH) (which are derived from Perennial) (12) were tolerant to the virus isolate we used. In Perennial, the donor of tolerance, several plants developed slight mosaic symptoms after inoculation, while most remained symptomless. When progenies of the symptomless plants were inoculated, the same variation in symptom response was obtained. The slight mosaic in the young growing leaves did not affect the recovery ability of Perennial plants.

When Perennial was crossed with belltype lines, the $\mathrm{F}_{1}$ plants were intermediate in their tolerance (symptom severity) to CMV (Table 2), indicating that the tolerance is incompletely dominant. In the segregating populations, variable degrees of symptoms were observed, and we could not define discrete classes of symptoms. We therefore divided the populations into three classes: plants displaying severe symptoms (pronounced mosaic, growth inhibition, and leaf deformation), mild symptoms (light mosaic, no leaf deformation), and no symptoms. The segregation

Table 1. Reaction of documented cucumber mosaic virus-resistant germ plasm

\begin{tabular}{|c|c|c|c|}
\hline \multirow[b]{2}{*}{ Accession } & \multicolumn{2}{|c|}{ No. of plants ${ }^{a}$} & \multirow{2}{*}{$\begin{array}{l}\text { Origin } \\
\text { of accession }\end{array}$} \\
\hline & Tolerant & Susceptible & \\
\hline 1986 & 0 & 15 & P.W. Bosland ${ }^{b}$ \\
\hline 1987 & 0 & 7 & P.W. Bosland \\
\hline $11,28,30,65,66,86$ & 0 & 17 & Z. Miladinovic $^{c}$ \\
\hline 67,87 & 2 & 15 & Z. Miladinovic \\
\hline 88,89 & 1 & 16 & Z. Miladinovic \\
\hline Milord & 0 & 14 & E. Pochard ${ }^{\mathrm{d}}$ \\
\hline ADH $210,230,248,249,260,815$ & 10 & 0 & E. Pochard \\
\hline Perennial & 13 & 0 & E. Pochard \\
\hline Yellow jalapeno & 2 & 27 & B. Villalon ${ }^{\mathrm{e}}$ \\
\hline Sweet chili long & 0 & 17 & B. Villalon \\
\hline Hidalgo serrano & 0 & 34 & B. Villalon \\
\hline
\end{tabular}

\footnotetext{
${ }^{a}$ Number of plants tested for each line.

b New Mexico State University, Las Cruces.

${ }^{c}$ Institute for Vegetables Palanka, Smed. Palanka, Yugoslavia.

d INRA, Avignon-Montfavet, France.

e Texas Agricultural Experiment Station, Weslaco.
}

Table 2. Response of tolerant and susceptible pepper lines and their progeny following mechanical inoculation with cucumber mosaic virus

\begin{tabular}{lrcrc}
\hline Line/population & \multicolumn{3}{c}{ Symptoms } & Total no. \\
\cline { 2 - 4 } & None & Mild & Severe & \\
\hline Maor & 0 & 0 & 44 & 44 \\
Perennial & 22 & 3 & 1 & 26 \\
F $_{1}$ (Maor $\times$ Perennial $)$ & 0 & 18 & 5 & 23 \\
F $_{2}$ (Maor $\times$ Perennial $)$ & 10 & 120 & 226 & 356 \\
BC $_{1}$-Maor & 0 & 15 & 179 & 194 \\
BC $_{1}$-Perennial & 16 & 53 & 13 & 82 \\
\hline
\end{tabular}

data (Table 2) indicated that the tolerance to CMV is controlled by two or three major genes. Chi-square tests for goodness of fit using the $\mathrm{F}_{2}$ data (the two susceptible classes were pooled) and $\mathrm{BC}_{1}$ to Maor best supported a three-gene model $(P=0.05$ and $P=0.4$, respectively). However, the backcross to Perennial supported a twogene model $(0.5<P<0.25)$.

Field performance. In order to evaluate the tolerant breeding lines for agronomic performance, CMV-inoculated plants placed in the field were scored for disease symptoms and fruit yield. Ninety-five percent of the varieties Maor, an Israeli belltype cultivar, and Osir, a newly released CMV-resistant hybrid (Claus Seed Co., France) showed symptoms early, with a significant reduction in fruit number, weight, and quality (Table 3). The tolerant breeding lines had variable levels of response to CMV inoculation. Lines 3990 and 3985 were highly tolerant, with a slight (but statistically not significant) decrease in fruit number and weight. Line 4125 was intermediate in its tolerance. Breeding lines 4173, 11976, and 12099 were the least tolerant lines tested, although they were better than Osir and Maor. No symptoms were observed on the control noninoculated plants, indicating that there was no virus spread among plants in the field.

Virus accumulation. We monitored CMV accumulation in the tolerant lines by ELISA, in order to determine the relationship between symptoms after inoculation and the virus titer found in the plants (Fig. 1). Nearly a week after inoculation in a greenhouse, all lines exhibited mosaic symptoms in the upper leaves. Thereafter, severity of symptoms increased in the susceptible cultivar Maor; whereas in the tolerant lines 3990 and 3985, the plants were symptomless. Intermediate tolerant lines expressed various degrees of light to medium mosaic symptoms.

Based on ELISA, the tolerant lines $3990,3985,4125$, and 4173 had significantly less virus than did the susceptible cultivar Maor 6 to 10 days after inoculation (Fig. 1). At later stages, the tolerant lines had about the same amount of CMV in the upper leaves as did the susceptible cultivar Maor. Moreover, there was no correlation between tolerance level (symptoms and fruit yield) and virus accumulation. The line 11976 had the lowest level of CMV titer but had a low level of tolerance (Table 3). The line 3985 was highly tolerant in the field but had the highest virus titer among the lines within the initial 6- to 10-day period.

The results described here were obtained by employing a single isolate of CMV. Recently, we collected from the field three different isolates of CMV based on symptoms and host range. All three were found to belong to subgroup I. The same results in terms of symptom production were obtained when the different pepper lines were 
inoculated with these CMV isolates (not shown).

\section{DISCUSSION}

We transferred tolerance to CMV from Perennial pepper into several bell-type lines. The selection was based on symptom severity in the greenhouse following mechanical inoculation with CMV. Selection under greenhouse conditions was as effective as selection under field conditions, as the most tolerant lines selected in the greenhouse were also the most tolerant based on field performance. Lines 3985 and 3990, and similarly tolerant lines (not shown), were determined to be the most tolerant ones under both conditions. In these two lines, there was almost no reduction in fruit number and size as a result of infection, and no viral symptoms were noted on the fruits. Hence, selection and stabilization of tolerant lines can be completed under greenhouse conditions. Such a level of tolerance to CMV is highly promising for protecting against natural field infection.

The analysis of $F_{1}$ plants indicated that the tolerance is incompletely dominant,

Table 3. Agronomic field performance of pepper lines following cucumber mosaic virus inoculation

\begin{tabular}{|c|c|c|c|c|c|}
\hline \multirow[b]{2}{*}{ Line } & \multicolumn{2}{|c|}{ Average no. of fruit per plant } & \multicolumn{2}{|c|}{ Average fruit weight (g) } & \multirow{2}{*}{$\begin{array}{c}\text { Degree of fruit } \\
\text { deformation }\end{array}$} \\
\hline & Control & Inoculated $^{\mathrm{a}}$ & Control & Inoculated $^{\mathbf{a}}$ & \\
\hline Osir & 11.3 & $6.2^{* *}$ & 144 & $72 * *$ & Severe \\
\hline Maor & 9.2 & $2.8 * * *$ & 124 & $54 * * *$ & Severe \\
\hline $3985\left(\mathrm{BC}_{5} \mathrm{~F}_{6}\right)$ & 8.7 & 8.5 & 85 & 82 & None \\
\hline $3990\left(\mathrm{BC}_{5} \mathrm{~F}_{6}\right)$ & 13 & 11.8 & 81 & 78 & None \\
\hline $4125\left(\mathrm{BC}_{5} \mathrm{~F}_{5}\right)$ & 8.1 & 8.9 & 98 & $79 *$ & Slight \\
\hline $4173\left(\mathrm{BC}_{5} \mathrm{~F}_{5}\right)$ & 12.6 & $9.2^{* *}$ & 128 & $84 * *$ & Moderate \\
\hline $11976\left(\mathrm{BC}_{5} \mathrm{~F}_{4}\right)$ & 10.7 & $8.9^{* *}$ & 98 & $76^{*}$ & Slight \\
\hline $12099\left(\mathrm{BC}_{5} \mathrm{~F}_{5}\right)$ & 11 & 9.7 & 94 & $67 * *$ & Moderate \\
\hline
\end{tabular}

${ }^{a}$ Significant difference (ANOVA) at * denotes $P<0.05$; ** denotes $P<0.01 ; * * *$ denotes $P<0.001$ when compared with noninoculated plants.

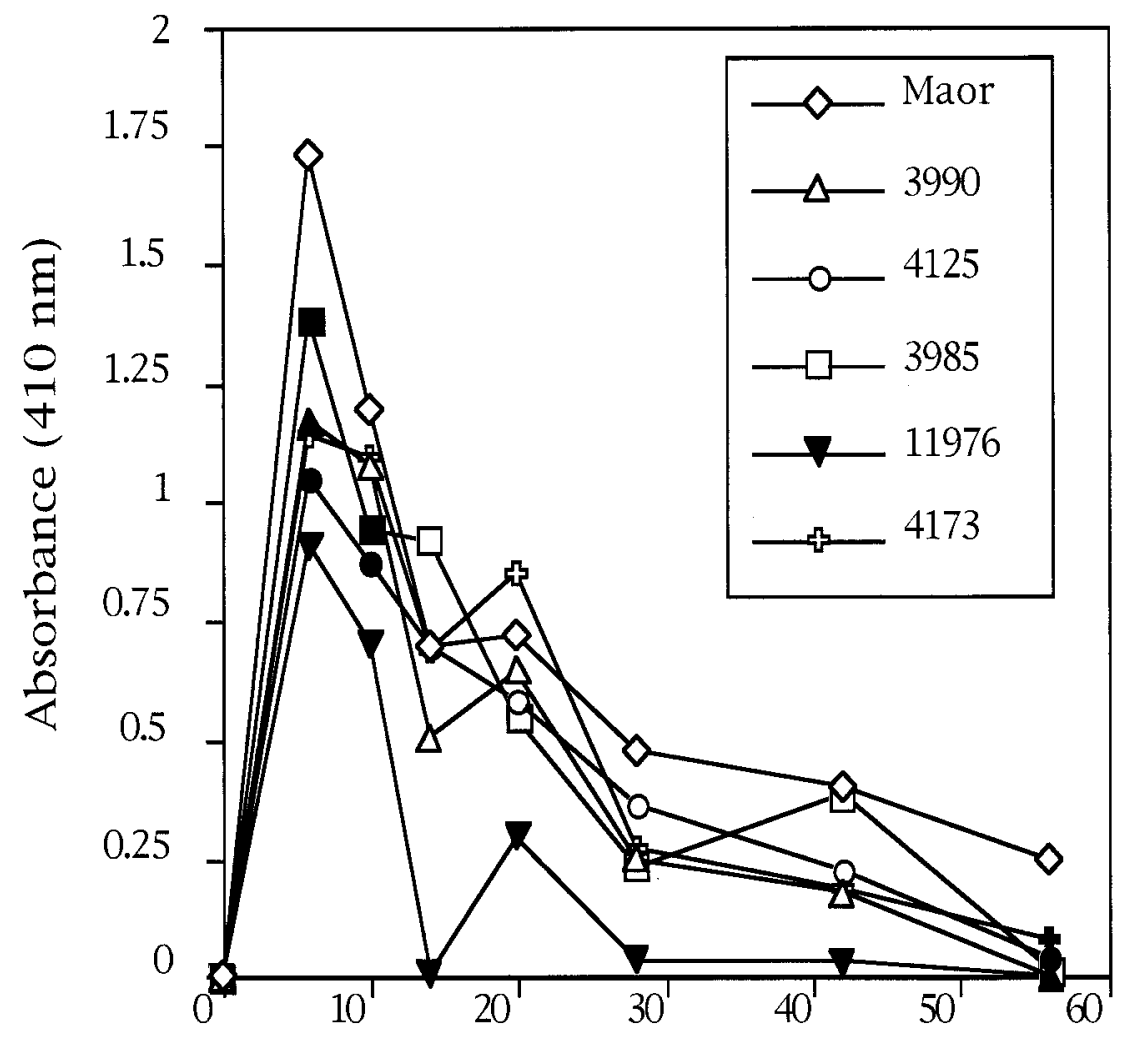

\section{Days after inoculation}

Fig. 1. Accumulation levels of cucumber mosaic virus (CMV) in upper leaves of six pepper lines quantitated by enzyme-linked immunosorbent assay. The results are the means of seven plants of each line after subtracting background values (taken from three noninoculated plants of each line). Solid symbols indicate significant difference at the 95\% level (Fisher's PLSD test) when compared with viral accumulation level in the susceptible Maor plants. since the $\mathrm{F}_{1}$ was intermediate in its level of tolerance. In addition, in the backcross to Perennial, plants with a mosaic as strong as that in Maor were detected. These results may indicate that some of the genes controlling the tolerance have variable expressivity; i.e., a given genotype is expressed phenotypically in different degrees due to strong influence of the environment. However, it is also possible that Perennial is heterozygous for minor genes controlling the tolerance to CMV, which may explain some of this variation. This possibility is supported by our results showing that the breeding lines 3985 and 3990 did not segregate; the CMV tolerance was stabilized. The existence and segregation of minor genes that control tolerance in addition to the major ones is also supported by the appearance of various degrees of tolerance in the backcross breeding lines and the continuous segregation of apparently tolerant plants.

Recently, Nono-Womdim et al. (7) studied CMV multiplication in the inoculated leaf in susceptible and resistant Capsicum lines. They concluded not only that Perennial is tolerant to CMV infection, but that CMV replication is inhibited as well. However, we found that there was no relationship between virus level in the upper leaves and degree of tolerance to the virus. These results suggest that inhibition of viral accumulation level per se is not the key to the tolerance; rather, the important attribute is the ability of the tolerant lines to recover from the infection and to tolerate viral levels that are detrimental to the susceptible host. However, it is also possible that the different results may be attributed to a differential response of Perennial to different $\mathrm{CMV}$ isolates.

Marco and Cohen (6) suggested that ELISA could be useful in pepper breeding programs by providing a quantitative evaluation of viral resistance. Our results demonstrate that using only ELISA for selection of breeding lines could be misleading.

\section{LITERATURE CITED}

1. Bansal, R. O., Aulakh, R. K., and Hundal, J. S. 1992. Reaction of different genotypes of pepper (Capsicum annuum) to cucumber mosaic virus. Pages 132-137 in: Proc. Meet. "Genet. Breed. Capsicum Eggplant", 7th, Rome, Italy.

2. Clark, M. F., and Adams, A. N. 1977. Characteristics of the microplate method of enzyme-linked immunosorbent assay for the detection of plant viruses. J. Gen. Virol. 34:475-483.

3. Fulton, R. W. 1958. Resistance in tobacco to cucumber mosaic virus. Virology 6:303-316.

4. Greenleaf, W. H. 1986. Pepper breeding. Pages 67-134 in: Breeding Vegetable Crops. M. J. Basset, ed. AVI Publishing, Westport, CT.

5. Lackney, V. K., Murphy, J. F., Prince, J. P., Loaiza-Figueroa, F., and Kyle, M. M. 1992. Comparative survey of sources of resistance to cucumber mosaic virus in pepper. Proc. Natl. Pepper Conf., Monterey, CA.

6. Marco, S., and Cohen, S. 1979. Rapid detec- 
tion and titer evaluation of viruses in pepper by enzyme-linked immunosorbent assay. Phytopathology 69:1259-1262.

7. Nono-Womdim, R., Gebre-Selassie, K., Polloix, A., Pochard, E., and Marchoux, G. 1993. Study of multiplication of cucumber mosaic virus in susceptible and resistant Capsicum annuum lines. Ann. Appl. Biol. 122:49-56.

8. Nono-Womdim, R., Marchoux, G., Pochard, E., Polloix, A., and Gebre-Selassie, K. 1991. Resistance of pepper lines to the movement of cucumber mosaic virus. J. Phytopathol. 132:21-32.

9. Nono-Womdim, R., Polloix, A., Gebre-Selassie, K., and Marchoux, G. 1993. Partial resistance of bell pepper to cucumber mosaic virus movement within plants: Field evaluation of its efficiency in southern France. J. Phytopathol. 137:125-132.

10. Palukaitis, P., Roossinck, M. J., Dietzgen, R. G., and Francki, R. I. B. 1992. Cucumber mosaic virus. Adv. Virus Res. 41:281-349.

11. Pochard, E. 1977. Methodes pour la letude de la resistance partielle au virus du concombre chez le piment. Pages 93-104 in: Capsicum 77, C.R. 3e. Congr. Eucarpia sur la Genetique a la selection du Piment, Montfavet, France.

12. Pochard, E., and Daubeze, A. M. 1989. Progressive construction of a polygenic resistance to cucumber mosaic virus in the pepper. Pages 189-192 in: Proc. Eucarpia Meet. Genet. Breed. Capsicum Eggplant, 7th, Kragujevac, Yugoslavia.

13. Rusco, J., and Csillery, G. 1980. Selection for
CMV resistance in pepper by the method developed by Pochard. Pages 37-39 in: Capsicum 80. 4th Eucarpia Meeting, Wageningen, The Netherlands.

14. Singh, J., and Thakur, M. R. 1977. Genetics of resistance to tobacco mosaic virus, cucumber mosaic virus and leaf curl virus in hot pepper (Capsicum annuum L.). Pages 119-123 in: Capsicum 77. 3rd Eucarpia Meeting, Montfavet, France.

15. Yoon, J. Y., Green, S. K., Tschanz, A. T., Tsou, S. C. S., and Chang, L. C. 1988. Pepper improvement for the tropics: Problems and the AVRDC approach. Tomato and Pepper Production in the Tropics. Pages 86-98 in: Proc. Int. Symp. Integrated Management Practices, Taiwan. 